\title{
盲導犬の早期適性判断への健康診断の利用
}

\author{
水越 美奈 1）2） 中村 透 2) \\ 1) 日本獣医生命科学大学獣医学部 \\ 2）財団法人日本盲導犬協会神奈川訓練センター
}

\section{Examination concerning aptitude judgment of the guide dog at an early stage by medical check-up}

\author{
Mizukoshi Mina $^{1)}{ }^{2}$, Nakamura Toru ${ }^{2}$ \\ 1) Nippon Veterinary \& Life Science University, Faculty of Veterinary Science \\ 2) Japan Guide Dog Association Kanagawa Training Center
}

\section{抄 録}

盲導犬の適性にはストレスに対する適応が影響すると仮定し、盲導犬候補犬に対して行われる健康診断の 中でストレスに関連すると考えられる白血球数や心拍数、血圧などの検査結果が盲導犬になった犬とならな かった犬での違いがあるかどうかを検討した。またそれらを訓練センターに入所翌日と入所 2 週間後で測定 し、訓練センターに入所するというストレスが関連するかどうかの検討も行った。その結果、検查日での相 違は見られなかったが、いずれの日程でも盲導犬になった犬とならなかった犬間で $\mathrm{R}-\mathrm{R}$ 変動率で相違が 見られた。被験数を増やして調査したところ結果は同じであった。これらの結果より、盲導犬の適性は訓練 センターへの入所という長期ストレスではなく心電龱検查を行うという一時的なストレスの適応に関連して いることが示唆され、心電図検査は早期適性検査の一つとして可能性があることが示唆された。

キーワード：盲導犬、早期適性診断、健康診断、心電図検查、 $\mathrm{R}-\mathrm{R}$ 変動率

\section{Abstract}

With the hypothesis that different sensitivity to stress would be seen between dogs that becomes guide dogs and dog not so, we compared the results of the number of white blood cells, the heart rate, and the blood pressure that related to their stress. It was thought that there might be differences not only in the sensitivity to stress, but also in the recovery from and the resistance against stress, and the same test was done the next day and two weeks after being moved to the training center from the puppy raiser's home. But there was little difference in the results from the next day and two weeks after, and between the dogs that became guide dogs and dogs that did not. However major difference between the dogs that became guide dogs and the dogs that did not was the fluctuation of their heart rates. The results were similar for the next day and 14 days later. Then, when the number of test dogs was increased and the fluctuations in the heart rates were investigated, the results were similar to the previous testing. According to these results, there are differences in the recovery and the reactions to short-term stress like the electrocardiogram measurement and tolerance against and the recovery from long-term stress including entering the training center and kennel life between dogs that become guide dogs and dogs that do not.

It was thought that this test was effective as one of the early aptitude judgments because the electrocardiogram was a test that was able to be relatively easy-to-use, and because the results were clear.

Keywords : guide dog for the blind, medical check-up, aptitude assessment at early stage, electrocardiogram, R-R volatility 


\section{序論}

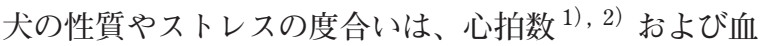
圧 $^{3)}$ の上昇と関連があるといわれており、また条件付け られた恐怖では心拍数は明らかに上昇するが血圧には関連 しない4）という報告がある。心臓の拍動は、自律神経系 によってリズムの調整がなされており、交感神経は緊張や 興奮など何らかのストレス状態になったときに優位となり、 反対に副交感神経が優位のときは、心臓の働きは抑制され る。したがって、心拍数や $\mathrm{R}-\mathrm{R}$ 間隔変動（心拍変動）は、 自律神経系の影響、さらにそれを変化させる原因となって いる精神的な安定度やストレスの程度などを類推すること ができると言われている。

盲導犬の適性では作業や行動の「安定性」、環境への 「順応性」および「不安」の程度が重要な位置を占めると 言われている。盲導犬の候補犬は、約 2 か月齢から約 1 年 齢の間、子犬飼育ボランティア宅で家庭犬として生活を送 った後に、盲導犬としての訓練を受けるために訓練センタ 一に入所する。家庭における生活から訓練センターでの生 活への変化は、生活環境や生活パターンの変化、約 1 年 間飼い主であった子犬飼育ボランティアとの別れなどがあ り、これらは大きなストレスの要因となると考えられる ${ }^{5)}$ 。

すなわち、この生活パターンの大きな変化に対する身体 的な応答は、上記の「安定性」「順応性」および「不安」 を評価する上で参考になりうると仮定し、盲導犬訓練犬に 対して訓練センター入所直後と訓練センターでの生活に慣 れてきた頃に血液検査、血圧、心拍数などの評価を行い、 それらの成績がその被検査犬の帰結（最終的に盲導犬にな つたか、行動的に盲導犬として不適格とされたか）により 相違があるか否かを比較検討した。さらにこれらの結果よ り、被検査犬の母集団を増やして検討を加えたので報告す る。

\section{方法}

試験 1 として(財) 日本盲導犬協会で 2003 年 6 月に盲導 犬候補犬として繁殖され、約 1 年間子犬飼育ボランティ アに育てられた後、盲導犬としての訓練を受けるために訓 練センターに戻ってきたラブラドールレトリバー 22 頭（雄 12 頭、雌 10 頭)、ゴールデンレトリバー 5 頭 (雄 5 頭、雌 0 頭) に対象とした。訓練センター入所後翌日と 14 日後に 体重測定と血液一般検査、血圧測定および心電困検査 (心拍数、 $\mathrm{R}-\mathrm{R}$ 変動率、心拍トレンド) を行った。試験 1 では、すべての值（体重、血液一般検査、血圧、心電図検
査）について全頭について入所翌日と 14 日後、それぞれ の検査日について盲導犬になった犬とならなかった犬で $\mathrm{t}$ 検定を行った。

血球計算はセルタック $\alpha$ ((株) 日本光電) および白血球 分類は目視法を用いた。血圧測定はデジタル自動血圧計手 首式 (オシロメトリック法、(株) オムロン) にて、前肢での 測定を行った。血圧測定に正確を期するために、上記の自 動血圧計で測定された脈拍数が聴診による心拍数と一致し ていることを確認した。心電罒検査は動物用心電困記録解 析装置 D500（(株）フクダエムイー工業）を用い、犬を左 横臥位に保定して 1 分間の測定を行った。

検査を行う際の保定は同一者とし、被検査犬は事前に実 験室 (訓練センター内医療室) と検査台 (診察台)への馴致 を行った。

評価を受けた犬の最終的な結果は盲導犬 13 頭、繁殖用 犬 1 頭、PR $\mathrm{PR}$ (盲導犬の啓発普及のために使用される犬) 3 頭、キャリアチェンジ犬（盲導犬として不適格とされ、 家庭犬になった犬） 10 頭（内、行動的理由 7 頭）であり、 今回は最終的に盲導犬に選出された 13 頭と行動的理由で 盲導犬として不適格とされた犬 7 頭について両者間の相違 について比較検討した。

さらに、試験 2 として 1996 年 11 月〜 2004 年 12 月まで に盲導犬候補犬として繁殖されたラブラドールレトリバー 128 頭（雄 66 頭、雌 62 頭）、ゴールデンレトリバー 3 頭 (雄 2 頭、雌 1 頭)、ラブラドールレトリバーとゴールデン レトリバーの交雑種 (F1) 7 頭 (雄 2 頭、雌 5 頭)の計 138 頭 (雄 70 頭、雌 68 頭) の 30 秒間の平均心拍数と心拍数 の変動を調査し、それぞれについて $\mathrm{t}$ 検定を行った。128 頭中、最終的に盲導犬になったのは 75 頭（雄 34 頭、雌 41 頭)、行動的理由で不適格とされた 63 頭 (雄 36 頭、雌 27 頭)であり、両者間について比較検討を行った。

\section{結果}

\section{I. 試験 1}

(1) 体重の変化

入所翌日と入所 14 日後での体重の増減は、盲導犬にな った犬ではー $0.12 \mathrm{~kg}$ 、行動的理由で盲導犬として不適格 とされた犬では+ $0.0067 \mathrm{~kg}$ であった。性別では、盲導犬 になった犬で雄十 $0.11 \mathrm{~kg}$ 、雌一 $0.45 \mathrm{~kg}$ 、行動的に盲導犬 として不適格だった犬で雄十 $0.25 \mathrm{~kg}$ 、雌一 $0.117 \mathrm{~kg}$ であ つた。検査した犬全頭での平均值はー $0.204 \mathrm{~kg}$ （雄十 $0.155 \mathrm{~kg}$ 、雌一 $0.46 \mathrm{~kg}$ ) であり、体重の変化は帰結の違い ではなく、雌雄差によるものであった（表 1 )。

（2）白血球数の変化 
総白血球数の測定および分類を行い、ストレスパターン に関連する分葉好中球数とリンパ球数をカウントした。総 白血球数は最終的に盲導犬になった犬に打いて、入所翌日 では $13,246 / \mu \ell 、 14$ 日後では $12,408 / \mu l 、 一$ 方、行動的 に盲導犬になれなかった犬では、 $12,162 / \mu \ell$ (入所翌日)、 $12,043 / \mu \ell(14$ 日後) であった。分葉好中球数は盲導犬に なった犬において、入所翌日では $7,795 / \mu \ell 、 14$ 日後で $7,774 / \mu \ell$ 、一方、行動的に盲導犬になれなかった犬では、 $7,316 / \mu l$ (入所翌日) $8,539 / \mu \ell$ (14 日後)であった。リ ンパ球数は盲導犬になった犬において、入所翌日では $3,762 / \mu l 、 14$ 日後で $3,117 / \mu \ell$ 、一方、行動的に盲導犬 になれなかった犬では、 $3,117 / \mu \ell$ (入所翌日) 、 $2,039 / \mu \ell$ (14 日後)であった (表 2)。以上のように、いずれも典型 的なストレスパターンは示さず、両者に打いて上記の項目 に有意差は認められなかった。

(3) 血圧の変化

最終的に盲導犬になった犬での入所翌日の最高血圧は $146 \mathrm{mmHg}$ 、最低血圧は $99 \mathrm{mmHg}$ 、行動的に盲導犬にな れなかった犬の最高血圧は $151 \mathrm{mmHg}$ 、最低血圧は
$103 \mathrm{mmHg}$ であり、14 日後の測定では、盲導犬になった 犬の最高血圧は $128 \mathrm{mmHg}$ 、最低血圧は $84.5 \mathrm{mmHg}$ 、行 動的に盲導犬になれなかった犬では最高血圧は $113 \mathrm{mmHg}$ 、最低血圧は $69 \mathrm{mmHg}$ であった（表 3 )。

第 1 回目と第 2 回目での血圧低下は、盲導犬になった犬 では最高血圧で $49 \mathrm{mmHg}$ 、最低血圧で $35.6 \mathrm{mmHg}$ 、一方、 行動的に盲導犬になれなかった犬ではそれぞれ $24 \mathrm{mmHg}$ 、 $29.3 \mathrm{mmHg}$ あり、盲導犬になった犬のほうが盲導犬にな れなかった犬に比較して最高および最低血圧とも減少率が 大きかったが、統計的な有意差は認められなかった。また 行動的に盲導犬になれなかった犬のうち、興奮して吠える ことが原因で盲導犬として行動的に不適格とされた犬で は、入所翌日の最高血圧が $150 \mathrm{mmHg}$ 、14 日後では $156 \mathrm{mmHg}$ で、最低血圧は入所翌日が $121 \mathrm{mmHg}$ 、14 日 後が $119 \mathrm{mmHg}$ であり、入所翌日と 14 日後の血圧の差異 はほとんどみられなかった。しかし、不安が理由で不適格 になった 2 個体では、入所翌日と 14 日後の最高血圧の差 異（減少）はそれぞれ $20 \mathrm{mmHg}$ と $60 \mathrm{mmHg}$ 、最低血圧の 差異（減少）はそれぞれ $20 \mathrm{mmHg} 、 66 \mathrm{mmHg}$ であり、盲

表 1 試験 1 : 将来の結果から見た訓練センターへの入所 (環境の変化)による体重の変化

\begin{tabular}{llll}
\hline & \multicolumn{1}{c}{ 全体 } & オス & メス \\
\hline 全体 $(\mathrm{n}=27)$ & $-0.204 \mathrm{~kg}$ & $0.155 \mathrm{~kg}$ & $-0.46 \mathrm{~kg}$ \\
\hline 盲導犬 $(\mathrm{n}=13)$ & $-0.12 \mathrm{~kg}$ & $0.11 \mathrm{~kg}$ & $-0.45 \mathrm{~kg}$ \\
\hline 行動的に盲導犬として & $0.0067 \mathrm{~kg}$ & $0.25 \mathrm{~kg}$ & $-0.117 \mathrm{~kg}$ \\
不適格とされた犬 $(\mathrm{n}=7)$ & & & \\
\hline
\end{tabular}

表 2 試験 1 : 将来の結果から見た訓練センター入所による白血球数の変化

\begin{tabular}{ccccccc}
\hline & \multicolumn{3}{c}{ 訓練センター入所翌日 } & \multicolumn{3}{c}{ 訓練センター入所 14 日後 } \\
\multicolumn{1}{c}{$/ \mu 1$} & TWBC & Segment & Lymph & TWBC & Segment & Lymph \\
\hline 全体 $(\mathrm{n}=27)$ & 13,086 & 7,738 & 3,437 & 12,304 & 7,937 & 2,742 \\
\hline オス全体 $(\mathrm{n}=17)$ & 12,620 & 7,442 & 3,702 & 11,730 & 7,541 & 2,689 \\
\hline メス全体 $(\mathrm{n}=10)$ & 13,383 & 7,928 & 3,263 & 12,700 & 8,194 & 2,776 \\
\hline 盲導犬 $(\mathrm{n}=13)$ & 13,246 & 7,795 & 3,762 & 12,408 & 7,774 & 3,117 \\
\hline 行動的に盲導犬として & 12,162 & 7,316 & 3,117 & 12,043 & 8,539 & 2,039 \\
不適格とされた犬 $(\mathrm{n}=7)$ & & & & & & \\
\hline
\end{tabular}

TWBC : 総白血球数、Segment : 分葉好中球数、Lymph : リンパ球数

表 3 試験 1 : 将来の結果から見た訓練センター入所による血圧の変化

\begin{tabular}{|c|c|c|c|c|}
\hline \multirow[b]{2}{*}{$\mathrm{mmHg}$} & \multicolumn{2}{|c|}{ 訓練センター入所翌日 } & \multicolumn{2}{|c|}{ 訓練センター入所 14 日後 } \\
\hline & 最高 & 最低 & 最高 & 最低 \\
\hline 全体（n=27） & 148 & 99 & 123 & 78.8 \\
\hline 盲導犬（n=13） & 146 & 96 & 128 & 84.5 \\
\hline $\begin{array}{l}\text { 行動的に盲導犬として } \\
\text { 不適格とされた犬 }(n=7)\end{array}$ & 151 & 103 & 113 & 69 \\
\hline
\end{tabular}

表 4 試験 1 : 盲導犬として不適格となった理由から見た血圧の変化

\begin{tabular}{ccccc}
\hline & \multicolumn{2}{c}{ 最高血圧 $\mathrm{mmHg}$} & \multicolumn{2}{c}{ 最低血圧 $\mathrm{mmHg}$} \\
入理由 & 入所翌日 & 入所 14 日後 & 入所翌日 & 入所 14 日後 \\
\hline 興奮して汱える & 150 & 156 & 121 & 119 \\
\hline 不安 1 & 126 & 106 & 69 & 49 \\
\hline 不安 2 & 180 & 120 & 120 & 54 \\
\hline
\end{tabular}


導犬として不適格となった理由によって入所翌日と入所 14 日後の最高および最低血圧の減少に差異が認められた（表 4)。

\section{(4) 心拍数の変化}

盲導犬になった犬の心拍数は、入所翌日の検査では平均 110 回/分（最低 72 最高 185 )、入所 14 日後の検査では 平均 111 回/分（最低 83 〜最高 137）であった。一方、行 動的に盲導犬にならなかった犬の入所翌日の検査では平均 101 回/分（最低 78 〜最高 147 ）、入所 14 日後では平均 91 回/分（最低 69 ～最高 128）であり、両者間の差異は認め られなかった（表 5)。

\section{(5) $R-R$ 間隔と $R-R$ 変動率}

$\mathrm{R}-\mathrm{R}$ 間隔は、入所翌日の検査で盲導犬になった犬では 平均 0.578 秒、行動的に盲導犬になれなかった犬では平均 0.621 秒、入所 14 日後の検査では、最終的に盲導犬にな った犬では 0.549 秒、行動的に盲導犬になれなかった犬で
は 0.688 秒であった。入所 14 日後の検査において、盲導 犬になった犬となれなかった犬の間に有意差 $(\mathrm{p}<0.05)$ が 認められた（表 6)。

$\mathrm{R}-\mathrm{R}$ 変動率は、入所翌日の検査で盲導犬になった犬で は平均 $8.698 \%$ 、なれなかった犬では $10.556 \%$ 、入所 14 日後の検査では盲導犬になった犬で $13.356 \%$ 、なれなか った犬では $13.081 \%$ \%あり、 R-R 間隔と同様に入所翌日 と入所 14 日後の結果の間で盲導犬になった犬、なれなか った犬ともに有意差はみられなかった。しかし、入所翌日 と入所 14 日後の検査において、盲導犬になった犬となれ なかった犬の間に有意差（p<0.05）が認められた（表 7)。

\section{（6）心拍数の変動傾向}

心電図を 1 分間継続して測定し、心拍数の変動傾向を 観察した。行動的に盲導犬として不適格とされた犬は最終 的に盲導犬になった犬と比較して心拍数の上下動の大きい 個体が多かった（表 8)。

表 5 試験 1 : 将来的な結果から見た訓練センター入所による心拍数の変化

\begin{tabular}{lcc}
\hline \multicolumn{1}{c}{ /分 } & 訓練センター入所翌日 & 訓練センター入所 14 日後 \\
\hline 全体 $(\mathrm{n}=27)$ & 108 & 106 \\
\hline 盲導犬 $(\mathrm{n}=13)$ & 110 & 111 \\
\hline 行動的に盲導犬として & 101 & 91 \\
丕適格とされた犬 $(\mathrm{n}=7)$ & & \\
\hline
\end{tabular}

表 6 試験 1 : 将来的な結果から見た $\mathrm{R}-\mathrm{R}$ 間隔の訓練センター入所による変化

\begin{tabular}{ccc|c}
\hline 秒 & 訓練センター入所翌日 & 訓練センター入所 14 日後 \\
\hline 全体 $(n=27)$ & 0.594 & 0.594 & \\
\hline 盲導犬 $(n=13)$ & 0.578 & 0.549 & $*$ \\
\hline 行動的に盲導犬として & 0.621 & 0.688 & \\
不適格とされた犬 $(n=7)$ & & & \\
\hline$* 0$ &
\end{tabular}

表 7 将来的な結果から見た $\mathrm{R}-\mathrm{R}$ 変動率の訓練センター入所による変化

\begin{tabular}{|c|c|c|}
\hline$\%$ & 訓練センター入所翌日 & 訓練センター入所 14 日後 \\
\hline 全体 $(n=27)$ & 10.074 & 11.618 \\
\hline 盲導犬 $(n=13)$ & 8.698 & 10.556 \\
\hline $\begin{array}{l}\text { 行動的に盲導犬として } \\
\text { 不適格とされた犬 }(n=7)\end{array}$ & 13.356 & 13.081 \\
\hline
\end{tabular}

表 8 将来の結果から見た訓練センター入所による心拍数の安定性

\begin{tabular}{|c|c|c|c|c|c|c|}
\hline 盲導犬 & 入所翌日 & 入所 14 日後 & キャリアチェンジ & 入所翌日 & 入所 14 日後 & $\mathrm{CC}$ 理由 \\
\hline & 安定 & 安定 & & 不安定 & 不安定 & 興奮 \\
\hline & 安定 & 安定 & & 安定 & 安定 & 犬に対して興奮 \\
\hline & 安定 & 安定 & & 不安定 & 不安定 & 犬に対して興奮 \\
\hline & 安定 & 安定 & & 不安定 & 不安定 & 興奮 \\
\hline & 安定 & 安定 & & 安定 & 安定 & 吠え \\
\hline & 安定 & 安定 & & 上昇 & 下降 & 不安 \\
\hline & 不安定 & 安定 & & 上昇 & 安定 & 不安 \\
\hline & 不安定 & 安定 & & & & \\
\hline & 安定 & $\mathrm{NA}$ & & & & \\
\hline & 安定 & 下降 & & & & \\
\hline & 安定 & 安定 & & & & \\
\hline
\end{tabular}




\section{II. 試験 2}

盲導犬になった 75 頭（雄 34 頭、雌 41 頭）と行動的理 由で盲導犬になれなかった 63 頭（雄 36 頭、雌 27 頭）間 で比較検討を行ったところ、心拍数、 $\mathrm{R}-\mathrm{R}$ 間隔では有意 差は認められなかったが、 $\mathrm{R}-\mathrm{R}$ 変動率において有意差 （p<0.05）がぬられた（表 9$) 。$

心拍数の変動は、盲導犬になった犬では最初から安定し ていた個体が $62.16 \%$ 、最初は不安定だったがその後安定 傾向をみせたものが $18.92 \%$ 、最初から最後まで不安定だ ったものが $18.92 \%$ \%゙った。これに対して行動的に盲導 犬として不適格とされた犬では、最初から安定していた個 体は $6.38 \%$ 、最初から最後まで不安定だったものが $93.62 \%$ \%りり、その傾向は両者間で大きく異なっていた (表 10)。

\section{考察}

盲導犬になる犬とそうでない犬では、ストレスの感受性 が違うという仮説 ${ }^{6)}$ に基づいて、ストレス反応に関連す るといわれている白血球数、心拍数および血圧の比較検討 を打こなった。盲導犬の適性は、ストレスに対する感受性 の大きさだけでなく、ストレスからの回復や抵抗性に関連 していると考え、試験 1 では訓練センターへの入所翌日と 14 日後に検查を設定した。しかし両日の成績にはほとん ど差異はみられなかった。

血圧の上昇はストレスに関与しているといわれているが、 最高血圧打よび最低血圧ともに盲導犬になった犬と行動的 に盲導犬になれなかった犬間では有意な差異は見られず、 両者で経時的な血圧の低下が認められた。これは入所後、 犬舎に慣れることによりストレスが軽減したことを示して いるのかもしれない。しかし血圧では、不適格になった理 由によって変化の違いがみられたことは興味深いが、1 1 頭 のみの結果であったのでそれで考察を行うことは不適当で
あろう。

試験 1 の検查項目の中で、盲導犬になった犬と行動的 に盲導犬にならなかった犬間で有意差がみられたのは、 R一 $\mathrm{R}$ 間隔、 $\mathrm{R}-\mathrm{R}$ 変動率であり、さらに心拍数の安定性でも 差異がみられた (表 $6,7,8)$ 。集団を増やした試験 2 では、 同様に $\mathrm{R}-\mathrm{R}$ 変動率で有意差がみられ、心拍数の安定性で も大きな差がみられた（表 9,10）。

これらの結果から、最終的に盲導犬になった犬とそうで ない犬とのストレス反応に対する相違は、訓練センターへ の入所、つまり知らないところに連れて来られたことや飼 育環境の変化という長期的なストレスよりも、心電四測定 のために横臥位にする、といった短時間の拘束ストレスに より現れたと言うことができる。つまり、突然、実験者で ある見知らぬ人に横臥位に拘束させられるような急激に訪 れたストレスに対して、一過性に心拍数は増加するが、そ の増加は盲導犬として行動的に不適格とされた犬と比較し て顕著でなく、かつその心拍数はすぐに安定する傾向を示 した。

結果については、検査の方法や実験者の違い (男か女か、 保定者は何名か、など）により、結果が左右されることも 考虑しなければいけないため、保定者は同一とし、犬自身 は事前に実験室 (医療室) や検査台 (診察台)に十分に馴 致した後に行った。そのため、これらについての影響はで きるだけ除外することができたと考えられる。

一般的にストレスがかかると交感神経が優位になり、そ の結果、心拍数や血圧の上昇が起こる。通常はこのような 瞬間的な交感神経の興奮が起こると、これを抑えるために 副交感神経が働くために、心拍数や血圧は次第に下降す る。しかし、非常に強いストレスがかかると交感神経の興 奋状態が持続する。これらの違いが心拍数の変動の相違と して現れたのでないかと考えられた。今回、心拍数の変動 は同胎の兄弟に打いても同じ傾向を示さずに差異が見られ たことから、この結果では遺伝的な影響が少ないことが示 唆された。

表 9 試験 2 : 将来的な結果から見た犬の心拍数、R-R 間隔、R-R 変動率の相違

\begin{tabular}{lcrrr|r}
\hline & 心拍数 $/ \mathrm{min}$ & $\mathrm{R}-\mathrm{R}$ 間隔 & $\mathrm{sec}$ & $\mathrm{R}-\mathrm{R}$ 変動率 & $\%$ \\
\hline 盲導犬 $(\mathrm{n}=75)$ & 104 & 0.594 & 10.922 & $-*-$ \\
\hline 行動的に盲導犬として & 111 & 0.567 & & 13.391 & \\
不適切とされた犬 $(\mathrm{n}=63)$ & & & & & \\
\hline * $\mathrm{p}<0.05$ & & &
\end{tabular}

表 10 試験 2 : 将来的な結果から見た犬の心拍数の安定性の相違

\begin{tabular}{lccc}
\hline & 安定 & 不安定 $\Rightarrow$ 安定 & 不安定 \\
\hline 盲導犬 $(\mathrm{n}=75)$ & $62.16 \%$ & $18.92 \%$ & $18.92 \%$ \\
\hline 行動的に盲導犬として & $6.38 \%$ & $0 \%$ & $93.62 \%$ \\
不適格とされた犬 $(\mathrm{n}=63)$ & & & \\
\hline
\end{tabular}


盲導犬としての適性を早期に把握することを目的とし て、ストレスに関連する項目を血液検查、血圧検查抢よび 心電図検査の中から選択し、午の成績について最終的に盲 導犬に選出された犬と行動的に盲導犬として相応しくない と判断された犬の間で比較した。その結果、ほとんどの検 查值に招いて入所翌日と 14 日後の間には有意差は2られ なかったが、心電図検查に打ける $\mathrm{R}-\mathrm{R}$ 間隔と $\mathrm{R}-\mathrm{R}$ 間隔 の変動率 (心拍数の変動) で明らかな差異がみられた。さ らに、例数を増やして調査してところ、 $\mathrm{R}-\mathrm{R}$ 間隔では有 意差は認められなかったが、 $\mathrm{R}-\mathrm{R}$ 変動率では同様に有意 差か認められた。心電図検查は比較的簡易に測定できる検 查であり、盲導犬訓練前には必ず行われる検查である。ま たその結果は比較的明膫であるため、心電図検査は早期の 盲導犬の訓練犬に対する適性判断の一つとして有効である 可能性が示された。今後さらなる検討を進めることによ り、実際的な適性判断のひとつとして使用できるのではな いかと期待される。

1) VINCENT, I.C. \& LEAHY, R.A.(1997). Real-time non- invasive measurement of heart rate in working dogs: A technique with potential applications in the objective assessment of welfare program. Vet J, 153(2), 179-183.

2) BODEY, A.R. \& MICHELL, A.R.(1996).Epidemiological study of blood pressure in domestic dogs. J Small Anim Pract, $37(3), 116-125$.

3) VINCENT, I.C. \& MICHELL, A.R.(1996).Relationship between blood pressure and stress-prone temperament in dogs. Physiol Behav, 60(1), 135-138.

4) ZHANG, W.N., MURPHY, C.A., FELDON, J.(2004).Behavioural and cardiovascular responses during latent inhibition of conditioned fear: Measurement by telemetry and conditioned freezing. Behav Brain Res, 154(1), 199-209.

5) TUBER, D.S., HENNESSY, M.B., SANDERS, S. et al. (1996). Behavioral and glucocorticoid responses of adult domestic dogs (Canis familiaris) to companionship and social separation. Journal of Comparative Psychology, 110 (1), 103-108.

6) GODDARD, M.E. \& BEILHARZ, R.G.(1983).Genetics of traits which determine the suitability of dogs as guide-dogs for the blind. Appl Anim Ethol, 9, 299-315. 